\title{
TIPOS DE VEGETAÇÃO PARA MEDIDAS COMPENSATÓRIAS DE CONTROLE PLUVIAL NA FONTE EM ZONAS SUBTROPICAIS
}

\author{
TYPES OF VEGETATION FOR COMPENSATORY MEASURES OF PLUVIAL
} CONTROL IN THE SOURCE IN SUBTROPICAL ZONES

\begin{abstract}
BÁRBARA KLósS TEIXEIRA ${ }^{1}$ e ANDRÉ de SOUZA SILVA²
${ }^{1}$ Arquiteta e Urbanista pela UCS, Mestranda em Arquitetura e Urbanismo pela UNISINOS. E-mail: barbara.bkt@gmail.com

${ }^{2}$ Arquiteto e Urbanista pela UNISINOS, Mestre em Planejamento Urbano e Regional pela UFRGS, Doutor em Planejamento Urbano e Regional pela UFRGS. Professor dos Cursos de Graduação e Pós-Graduação em Arquitetura e Urbanismo da Escola Politécnica da UNISINOS. E-mail: silandre@unisinos.br
\end{abstract}

\section{RESUMO}

Este artigo apresenta algumas das espécies de plantas mais adequadas para três tipos de sistemas de drenagem urbana, são eles: canteiros pluviais, contenções vegetadas e biovaletas. A definição das espécies sugeridas para o plantio foi baseada nos seguintes fatores: espécies nativas, forma e floração das plantas, resistência e baixa manutenção. Para os jardins de chuva se destacam as espécies do biotipo macrófitas aquáticas anfíbias pois apresentam uma maior resistência a períodos de alagamentos e secas. As valetas ecológicas buscam a permeabilidade e purificação das águas visto que os recursos hídricos retornam para o meio ambiente. Já no âmbito das contenções busca-se a característica de resistência, buscando a estabilidade dos taludes, raízes abundantes cumprem essa função, remetendo as espécies trepadeiras, gramíneas e arbustos. Verifica-se assim, a importância das técnicas da infraestrutura verde que podem evitar inconvenientes futuros, relacionados à densidade urbana, e ainda contribuir com a composição de ambientes sustentáveis.

Palavras-chave: Vegetação; Drenagem Urbana; Espécies; Infraestrutura Verde. 


\begin{abstract}
This article presents some of the most suitable plant species for three types of urban drainage systems: compacted rain gardens, vegetated restraints and bio-ditches. The definition of the species suggested for planting was based on factors such as native species, form and flowering of the plants, resistance and low maintenance. Amphibian macrophyte aquatic biotypes are recommended for rain gardens because they present a better resistance to periods of floods and droughts. Ecological ditches are adequate for permeability and purification of waters because the hydric resources return to the environment. In the scope of the contentions, the characteristic of resistance is necessary. Abundant roots fulfill the function of stabilizing the slops, being recommended climbing plants, grasses and shrub species. So, it is evidenced how important is the existence of alternative strategies able to avoid future inconveniences related to urban density and also to contribute to the composition of sustainable environments.
\end{abstract}

Keywords: Vegetation; Urban Drainage; Species; Green Infrastructure.

\title{
1. INTRODUÇÃO
}

A presença da vegetação exerce importantes funções na cidade, agindo no microclima urbano, diminuindo a radiação solar, qualificando a velocidade e direção dos ventos, reduzindo os ruídos urbanos e minimizando a poluição do ar (MASCARÓ; MASCARÓ, 2010). Os espaços vegetados também são responsáveis por qualificar a paisagem urbana atraindo as pessoas para o ambiente aberto, transcorrendo assim, a maior movimentação nas vias públicas, que por sua vez estimula o comércio e o turismo local, contribuindo com a valorização de propriedade e promovendo a segurança das cidades (JACOBS, 2003).

Além dos problemas ambientais urbanos, a vegetação também ameniza as tensões sociais, pois proporciona um espaço de aproximação do ser humano com a natureza. A rotina cansativa imposta pela vida urbana pode ser atenuada por ambientes naturais que possam estimular atividades como caminhadas e passeios, além da possibilidade de convivência entre os moradores nas cidades nesses espaços. Esse benefício ligado ao lazer está também associado à função psicológica de aliviar o estresse. Então, a presença de vegetação traz benefícios psicológicos, fisiológicos, cognitivos e comportamentais (MAGALHÃES; CRISPIM, 2003). 
A vegetação no meio urbano é de fundamental importância para o equilíbrio do ecossistema local e à qualidade de vida da população, reduzindo os aspectos negativos causados pela urbanização como a impermeabilização dos solos, diminuição das áreas verdes, aumento da temperatura do ar, superaquecimento dos materiais e superfícies dentre outros. Segundo Sousa et al. (2014), a qualidade de vida esta relacionada com a utilização dos recursos naturais, ocasionando um problema de escassez devido ao seu consumo exagerado. A crescente urbanização, muitas vezes, vem esquecendo os aspectos regionais e diminuindo consideravelmente os espaços verdes. Esta ocupação pouco planejada, associada à falta de áreas verdes, vem modificando as características climáticas resultando na redução do conforto ambiental. Essas atitudes originaram um cenário onde as áreas urbanizadas são agravadas pela poluição dos rios, do solo e do ar, impermeabilidade das superfícies e falta de arborização (SOUSA et al, 2014).

Tendo em vista o que foi exposto, como inserir a vegetação no meio urbano de a fim de mitigar esses efeitos? E, ainda, como valorizar as vantagens providos pela vegetação? Parte-se do princípio que a utilização da vegetação na infraestrutura urbana, inserida como meio de contenção geológica e contenção das águas pluviais através de jardins de chuva e biovaletas, trazem vantagens como: (i) redução da degeneração das águas subterrâneas; (ii) maior permeabilidade das águas das chuvas; (iii) contribui na qualidade do ambiente através da inclusão de massas vegetais na paisagem; (iv) diminui o perigo de alagamentos; (v) reduz as impurezas na água e; (vi) ameniza o gasto com a drenagem e com as contenções.

O objetivo desse trabalho consiste em abordar a respeito de melhores práticas de manejo das águas pluviais a fim de diminuir os impactos ambientais gerados com as tecnologias convencionais, indicando espécies vegetais para os sistemas de biorretenção. Utiliza-se o método de levantamento bibliográfico, expondo as técnicas de inserção da vegetação na infraestrutura da paisagem pela visão dos autores Juan Luís Mascaró e Lúcia Mascaró (2010), abordando os aspectos de purificação das águas, permeabilidade do solo e umidade do ar. Como complementação, foram apresentados conceitos da autora Vasconcellos (2015) que embasaram as tipologias para manejo da drenagem urbana. Foram expostas algumas técnicas de infraestrutura verde para a utilização da vegetação no ambiente urbano, consistindo em: canteiros pluviais, biovaletas e contenção geológica. Além disso, foram sugeridas algumas espécies que se adaptam melhor a função apresentada no item anterior, embasadas, principalmente, nos autores Lorenzi (1992), Marchi e Barbieri (2015) e Stumpf (2009), visando a aplicação em zonas de clima subtropical. 


\section{IMPORTANCIA DA BIODIVERSIDADE E DAS ESPÉCIES NATIVAS}

A vegetação nativa é o resultado da interação dos diversos fatores ambientais presentes no espaço, servindo como indicador para algumas características do meio ambiente. A evolução da vegetação decorreu do processo evolutivo do espaço, sendo que representam os indivíduos que sobreviveram a todas as alterações climáticas, de relevo e hídricas se mostrando as mais aptas para o meio onde vivem. Muitos fatores são responsáveis pela grande variação dos tipos de vegetação presentes em um determinado espaço que, dependendo do quão diverso é o ambiente, maior ou menor variedade de espécies vegetais existirá. Giacomeli (2013) afirma que para potencializar os benefícios proporcionados pela vegetação é importante que a composição das espécies seja o mais diversificado possível (inserindo diferentes tipos de famílias e espécies); e deve-se priorizar as espécies nativas locais e regionais, pois são mais resistentes e adaptadas.

Sobreira et al (2014) afirmam que a proteção da vegetação nativa é fundamental para a conservação da biodiversidade contribuindo para a sobrevivência da diversidade biológica, pela preservação das espécies que incidem no local e para o controle da qualidade e da quantidade de água devido a influência que a vegetação exerce na disponibilidade hídrica para abastecimento humano. Conforme os mesmos autores, a função da vegetação nativa controla, também, a drenagem superficial e erosão do solo, evitando inundações.

A redução das áreas ocupadas por massas vegetais nativas tem levado a perda de biodiversidade e ao empobrecimento dos recursos naturais presentes no ambiente. Seoane (2006) considera que com o avanço do processo de desflorestamento, causado pela urbanização, as paisagens tendem a reter uma amostra desvalida da biodiversidade original do espaço. As parcelas remanescentes tornam-se ecologicamente semelhantes, dominadas por espécies oportunistas adaptadas a doenças, resistentes ao fogo e com baixo valor comercial. Portanto, no desenho de paisagens ecológicas, é fundamental que se utilize espécies nativas para manter a integridade da biodiversidade ambiental e promover a resiliência das cidades.

Lorenzi e Souza (2001) estabelecem que os efeitos visuais das plantas, correspondem às características morfológicas como inflorescência, folha, copa e tronco, as quais devem ser determinadas em função dos aspectos de cor, forma, brilho, textura, volume e altura. O Brasil é mundialmente conhecido por sua ampla biodiversidade, segundo 
Mello Filho (1985) há entre 5000 e 6000 espécies de árvores passíveis de serem usadas no paisagismo. Dentre essas espécies destacam-se as plantas produtoras de flores, com cores diversas, tornando possível e recomendável a utilização das mesmas na composição paisagística dos espaços.

Rizzini e Mors (1995) salientam que no Brasil existe cerca de 480 espécies nativas de palmeiras, sendo as que predominam atualmente na paisagem são espécies exóticas. Os exemplares nativos possuem grande valor econômico, mas são cultivados no exterior, isto acontece não apenas com as palmeiras, mas também com diversos outros grupos de plantas. Segundo Stumpf et al. (2015), no cenário do paisagismo nacional aconteceu uma substituição das espécies nativas pelas exóticas, devido à falta de informações para utilização de espécies nacionais em projetos. Inúmeras espécies nativas possuem características de serem usadas no paisagismo, no entanto, percebe-se uma reincidência de espécies exóticas que se tornaram consagradas e aceitas pela população, muitas vezes inadequadas para a função atribuída. Cabe salientar ainda que muitas espécies nativas existentes em áreas ameaçadas pelo processo de urbanização podem se extinguir. Todavia, a introdução das plantas nativas em cultivo paisagístico pode ser um instrumento de conservação destas espécies.

A utilização de vegetação nativa nos projetos paisagísticos proporciona a preservação de espécies de seres vivos e amplia a biodiversidade nestes ambientes, contribuindo para amenizar o impacto ambiental gerado pelas cidades, impedindo conurbações urbanas e valorizando a identidade local. Portanto, a preservação das espécies vegetais é fundamental para preservação ambiental, visto que a vegetação original é um recurso natural básico, sendo um instrumento para mitigar os efeitos da poluição atmosférica e alterações microclimáticas.

\section{BENEFÍCIOS DA VEGETAÇÃO}

As técnicas da infraestrutura verde atuam como estratégias que podem evitar futuros inconvenientes e ainda contribuir com a composição de ambientes sustentáveis. A utilização da vegetação como forma de contribuir com o desenvolvimento dos serviços ecossistêmicos beneficia-se com as funções que a natureza desempenha no ambiente. Segundo McHarg (2000:26), "o homem e a natureza são indivisíveis", a relação direta entre o ambiente natural e o construído pode ser efetivada através da conservação das condições ecológicas, desse modo, a infraestrutura verde pode se tornar 
uma parcela significativa do espaço urbano. Vargas e Pellegrino (2017) afirmam que a vegetação proporciona: (i) a diminuição do impacto das gotas de chuva; (ii) a redução da velocidade do escoamento das águas das chuvas; (iii) garante a estabilidade do solo através das raízes das plantas; (iv) filtra os sedimentos e poluentes trazidos pelo escoamento e; (v) contribui com a permeabilidade e evapotranspiração.

\subsection{Radiação solar}

Romero (2001) afirma que uma área vegetada pode absorver maior quantidade de radiação solar e, por sua vez, irradiar uma quantidade menor de calor que qualquer superfície construída, uma vez que grande parte da energia absorvida pelas folhas é utilizada para seu processo metabólico, enquanto em outros materiais toda a energia absorvida é transformada em calor.

\subsection{Microclima}

A vegetação contribui de forma significativa para o estabelecimento dos microclimas. O próprio processo de fotossíntese auxilia na umidificação do ar através do vapor d'água que libera. Em geral, a vegetação tende a estabilizar os efeitos do clima sobre seus arredores imediatos, reduzindo os extremos ambientais. De acordo com Mascaró (2010), a arborização relacionada ao ângulo de obstrução do sol e a geometria do espaço agregam aspectos positivos quanto a redução das ilhas de calor.

\subsection{Ventos}

Segundo Mascaró e Mascaró (2010), a ventilação influencia significadamente na ambiência dos espaços, interferindo na sensação térmica dos usuários. Afirma ainda que as características das espécies arbóreas são fatores determinantes nas condições de ventilação de um local. Conforme Romero (2001), o aproveitamento da vegetação para a ventilação urbana é fundamental, o movimento do ar no meio urbano afeta especificamente os pedestres e as edificações (aumentando as perdas de calor por convecção ou levando calor e poeira).

Através do uso de espécies de porte superior à altura média das edificações e do posicionamento adequado pode-se canalizar o vento. Árvores de porte pequeno e agrupadas criam áreas abrigadas em calçadas onde a intensidade do vento causa desconforto. 
A vegetação pode alterar a direção e a velocidade do vento, árvores e arbustos podem ser inseridos para que modifiquem o percurso do fluxo de ar e melhorem o conforto térmico do espaço urbano (MASCARÓ, 2010). Barreiras vegetais também podem ser inseridas na paisagem de modo que barrem os ventos de inverno e permitam a passagem nos ventos de verão, funcionando, também, como um redutor da velocidade do vento, reduzindo as zonas de turbulência, devido a permeabilidade da vegetação.

\subsection{Sombreamento}

A principal função da arborização no meio ambiente urbano, conforme Mascaró (2010), é de sombreamento. As árvores de grande porte, nas vias públicas, aumentam o sombreamento da vegetação e reduzem os efeitos das características espaciais do recinto urbano. Devido à energia que é gasta nos processos fisiológicos e a quantidade de vapor de água que produz, a vegetação constitui o material ideal para ser utilizado como sombreamento de verão da cidade.

\subsection{Umidade relativa do ar}

A presença de árvores provoca, também, um aumento na umidade relativa do ar. As copas das árvores e o tipo foliar estão diretamente relacionadas com o fenômeno, copas mais densas e folhas mais largas retém mais água e aumentam a densidade relativa do ar. Mascaró e Mascaró, 2010, afirmam que, para regiões onde a umidade do ar é baixa, são indicadas espécies com folhas pequenas, claras e lisas, pois produzem mais umidade, já em locais onde a umidade relativa do ar é elevada, sugere-se o oposto: plantas com folhas grandes e rugosas que evitam o aumento da mesma.

\section{6 Águas}

Conforme Almeida et al (2007), o destino incorreto das águas urbanas causa maus odores, contaminação da água potável e mortalidade dos peixes. O uso da vegetação buscando a purificação e tratamento da água representa uma tecnologia eficaz e de baixos custos energéticos e econômicos se mostrando como uma opção sustentável aos sistemas de infraestrutura cinza. Em termos de permeabilidade do solo, segundo Bargos e Matias (2011), a falta de infiltração do solo, ocasionada pela alta taxa de ocupação das cidades, causa o aparecimento de erosões, alagamentos e inundações, sobrecarregando o sistema de drenagem das águas pluviais. 
As plantas melhoram a qualidade da água através transferência de oxigênio feito pelas raízes. Segundo Dias et al. (2002), os sistemas de tratamento de água podem conter uma grande variedade de tipos de plantas, podendo se classificar como: flutuantes, submersas ou emergentes. A contribuição da vegetação na desidratação e na evapotranspiração aumenta significativamente o processo do tratamento dos efluentes. Dias et al (2002), afirmam ainda que as plantas são responsáveis pela condução da água ao longo dos seus rizomas estabelecendo permanentemente micro canais e passagens que impedem a colmatação.

Galindo et al (2008) afirmam que quando o solo fica exposto, sem a ocorrência de cobertura vegetal, forma-se de uma camada superficial, resultante do impacto direto das gotas de chuva, reduzindo a infiltração da água e aumentando o escoamento. Isto diminui as possibilidades de estabelecimento da cobertura vegetal e aumenta os riscos de enchentes e alagamentos. Os solos descobertos são altamente susceptíveis à erosão, causando uma remoção líquida de nutrientes das áreas degradadas.

\subsection{Aplicação da Infraestrutura verde para o manejo das águas pluviais.}

A infraestrutura verde busca se apropriar dos mecanismos naturais oferecidos pela natureza a fim de aplica-los nas cidades como forma de qualificar e auxiliar os sistemas de águas urbanas (CORMIER e PELLEGRINO, 2008). As principais contribuições desse sistema consistem na retenção das águas pluviais e no aumento da superfície vegetada (MEDEIROS, 2015). As tipologias apresentadas servem como uma ferramenta a ser utilizada para solucionar problemas provenientes da falta de drenagem urbana.

\section{ESPÉCIES VEGETAIS E MELHORES PRÁTICAS DE MANEJO DE DRENAGEM}

Segundo Vasconcellos (2015), o manejo das águas pluviais, através de sistemas de infraestrutura urbana vegetados como os canteiros pluviais, as contenções vegetadas e as biovaletas, dentre outros, contribuem com a infiltração, detenção, condução ou purificação das águas pluviais. Vasconcellos (2015) afirma ainda que a infraestrutura verde proporciona a conservação da biodiversidade, o favorecimento ao funcionamento dos sistemas naturais, a preservação dos habitats naturais, a proteção das florestas, a amenização climática, a economia, a prevenção de enchentes e processos erosivos, a promoção da saúde física e mental e o aumento da qualidade de vida. 
Para cada sistema (canteiros pluviais, as contenções vegetadas e as biovaletas) existem espécies vegetais mais aptas (figura 01) para determinada função. De acordo com Sousa et al (2014), deve-se ainda evitar que as espécies que sejam agressivas ou nocivas. Segundo Cormier e Pellegrino (2008), espécies vegetais devem estar adaptadas ao lugar. As espécies nativas são as mais indicadas ao local em que vivem, pois promovem a preservação da flora local, enfatizam a identidade do lugar, necessitam de baixa manutenção e criam condições favoráveis ao desenvolvimento fauna regional. Indica-se ainda que se utilize uma ampla quantidade de espécies de maneira que se aumente a biodiversidade evitando, assim, a proliferação de pragas.

\begin{tabular}{l|ccc}
\hline Critérios & Canteiro Pluvial & Contenções & Biovaletas \\
\hline Espécie nativa & $\mathbf{X}$ & $\mathbf{X}$ & $\mathbf{X}$ \\
Porte e forma diversos & $\mathbf{X}$ & $\mathbf{X}$ & $\mathbf{X}$ \\
Resistência & $\mathbf{X}$ & $\mathbf{X}$ & $\mathbf{X}$ \\
Baixa manutenção & $\mathbf{X}$ & $\mathbf{X}$ & $\mathbf{X}$ \\
Filtra a água & $\mathbf{X}$ & & \\
Suporta inundações temporárias & $\mathbf{X}$ & $\mathbf{X}$ & \\
Raízes pivotantes & & $\mathbf{X}$ & $\mathbf{X}$ \\
Densidade foliar & & $\mathbf{X}$ & $\mathbf{X}$ \\
Baixa demanda de insumos no & & & $\mathbf{X}$ \\
substrato & & & \\
Crescimento rápido & & & \\
Raízes profundas & & & \\
Rápida regeneração & & & \\
\hline
\end{tabular}

FIGURA 01. Critérios para definição das espécies. Fonte: Autores (2008)

Portanto, a definição das espécies que serão indicadas na sequência está fundamentada nos seguintes fatores: espécies nativas, porte e forma das plantas, resistência e baixa manutenção. As fichas que fazem parte desse trabalho foram adaptadas de Ely et al. (2010), visto que essas fichas caracterizam satisfatoriamente os atributos formais, funcionais e temporais de cada espécie. Cabe salientar ainda que foram propostas algumas espécies vegetais, no entanto existe um número muito maior de exemplares aptos para esses ambientes. 


\subsection{Sistema de canteiros pluviais}

Segundo Cormier e Pellegrino (2008) os canteiros pluviais (também chamados de jardins de chuva) recebem e tratam as águas do escoamento superficial. $O$ volume de água se acumula em depressões e depois é infiltrada pelo solo. A ação biológica das plantas e dos microrganismos presentes no solo removem substancias toxicas presentes nas águas da chuva e promovem a retenção do fluxo das águas pluviais. Segundo Vasconcellos (2015), as funções hídricas são: purificação por sedimentação, filtração e absorção biológica, detenção e infiltração.

Podem ser usados em espaços distintos assumindo tamanhos e formas variáveis. A utilização desse mecanismo contribui de diversas formas com o ambiente urbano como: diminuição da contaminação das águas subterrâneas, permite a maior permeabilidade das águas pluviais, contribui na ambiência do espaço através da inserção da vegetação na paisagem, reduz o risco de inundações, melhora a qualidade da água e diminui o custo da infraestrutura de drenagem. Os canteiros pluviais (figura 02) podem ter infiltração no solo e extravasor de água ou, também, pode ter seu sistema elaborado de forma que não tenha infiltração no solo, contribuindo apenas com a evaporação, evapotranspiração e transbordamento.

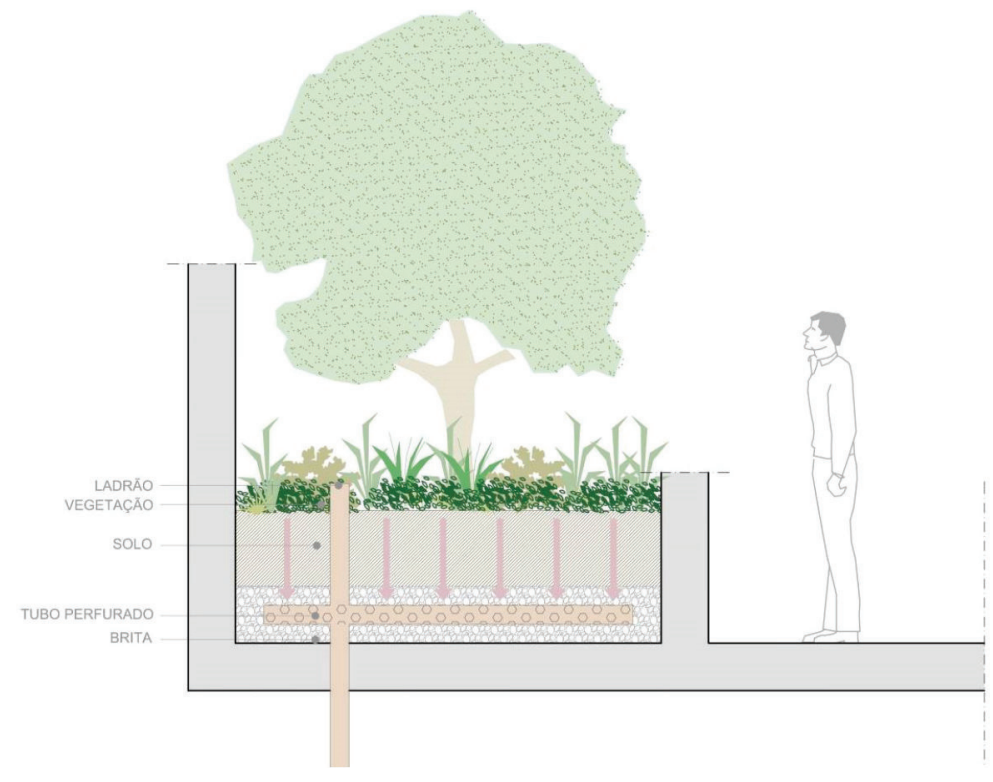

FIGURA 02. Esquema de um canteiro pluvial. Fonte: Adaptado pelos autores de Cormier e Pellegrino (2008)

As plantas selecionadas devem resistir a inundações temporárias e contribuir com a filtração da água, visto que as espécies vegetais não estarão submersas na água em todas as estações do ano, indica-se a utilização de macrófitas aquáticas anfíbias, 
também chamadas de semiaquáticas, que possuem suas raízes fixas no substrato e podem viver tanto em área alagada, como fora da água (ALMEIDA, 2012). Suas características biológicas permitem a absorção de grandes quantidades de poluentes e sua estrutura radicular forma uma espécie de grelha que possibilita a detenção de partículas finas. Além disso, promove a oxigenação do solo garantindo a porosidade necessária para a aeração das plantas, contribuindo, também, com a drenagem do ambiente (THOMAZ e BINI, 1998). Esse biotipo de planta é utilizado em tratamento de efluentes e atua como um indicador biológico da qualidade da água (ESTEVES e CAMARGO, 1986). As figuras 03 a 07 trazem espécies vegetais adequadas para serem plantadas em canteiros pluviais, respeitando as características biológicas de zonas subtropicais e relacionando com o porte da espécie vegetal.

Terras muito úmidas apresentam baixa disponibilidade de oxigênio, ocasionando o apodrecimento das raízes em espécies não adaptadas a esse tipo de ecossistema, porém, esses ambientes possuem uma extensa diversidade espécies vegetais, não só funcionando como conexão entre os sistemas terrestres e aquáticos, como também comportando uma importante biodiversidade para o ambiente. Além disso, os ecossistemas presentes nas áreas úmidas podem conter e filtrar grandes volumes de água, regulando os fluxos hídricos nos espaços nos quais estão presentes. Foram selecionadas algumas árvores e herbáceas que se caracterizam pela resistência adequada para suportar condições prolongadas do substrato alagado.
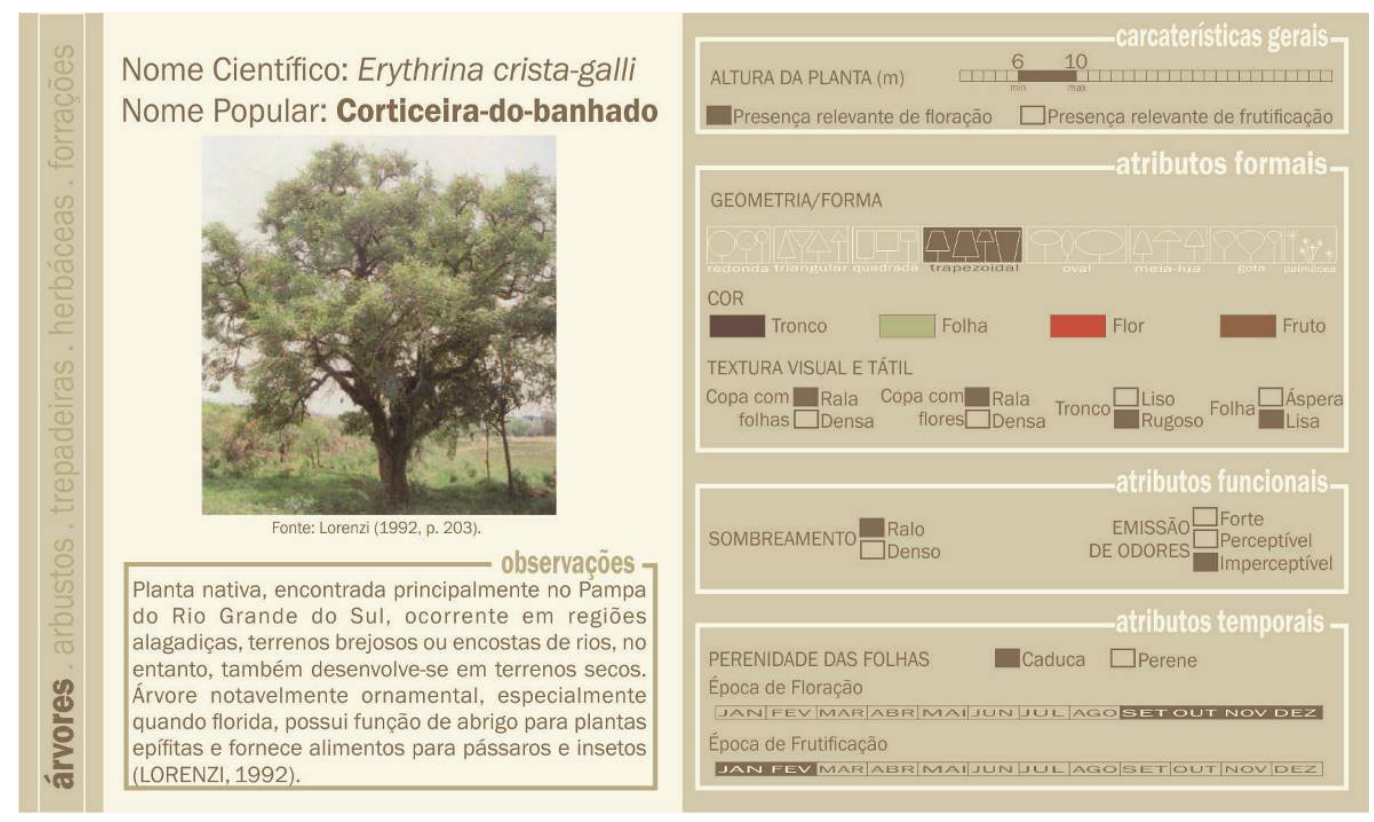

FIGURA 03. Espécie indicadas para a composição dos jardins de chuva subtropical (árvore). Fonte: Autores (2018) 

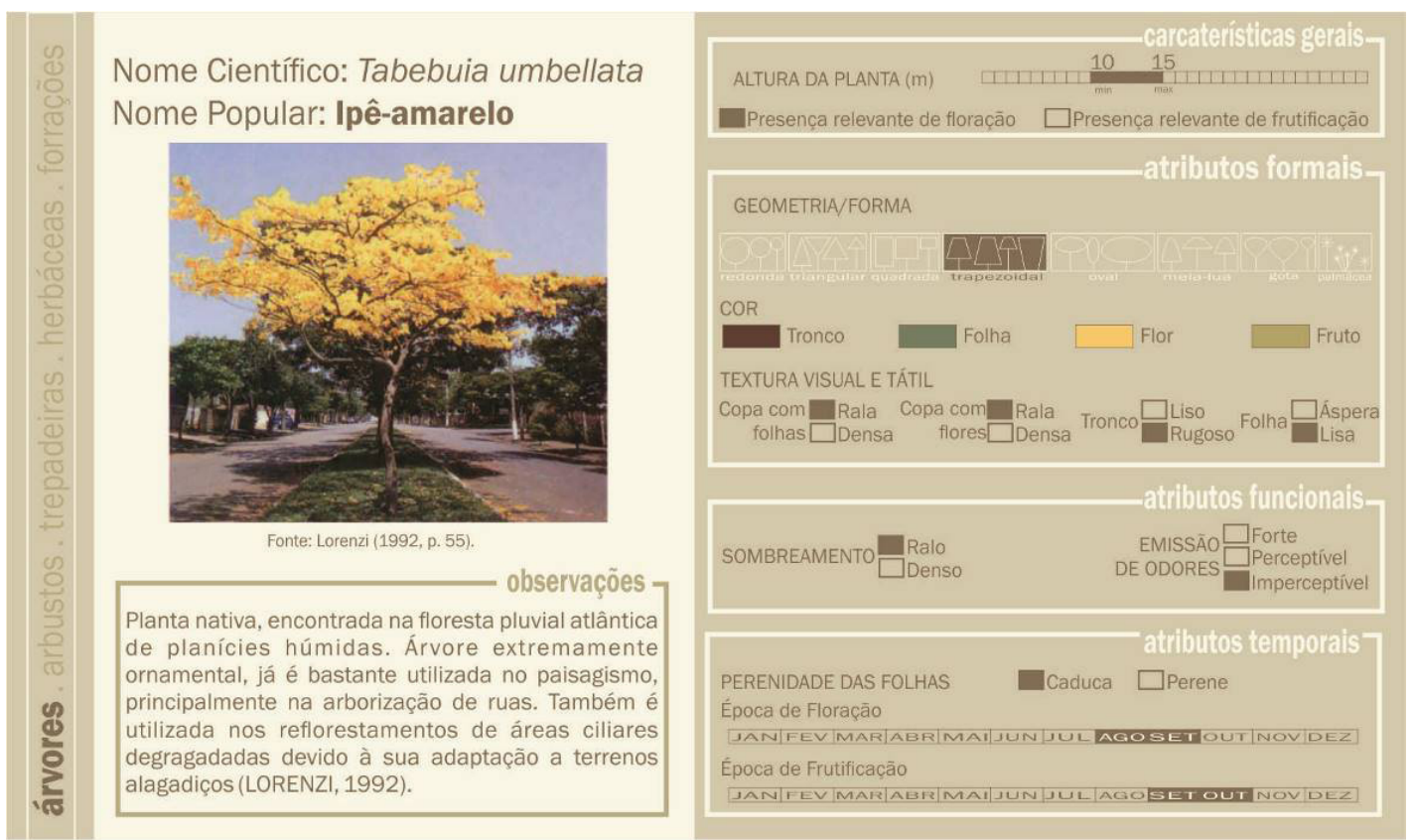

FIGURA 04. Espécie indicadas para a composição dos jardins de chuva subtropical (árvore). Fonte: Autores (2018)
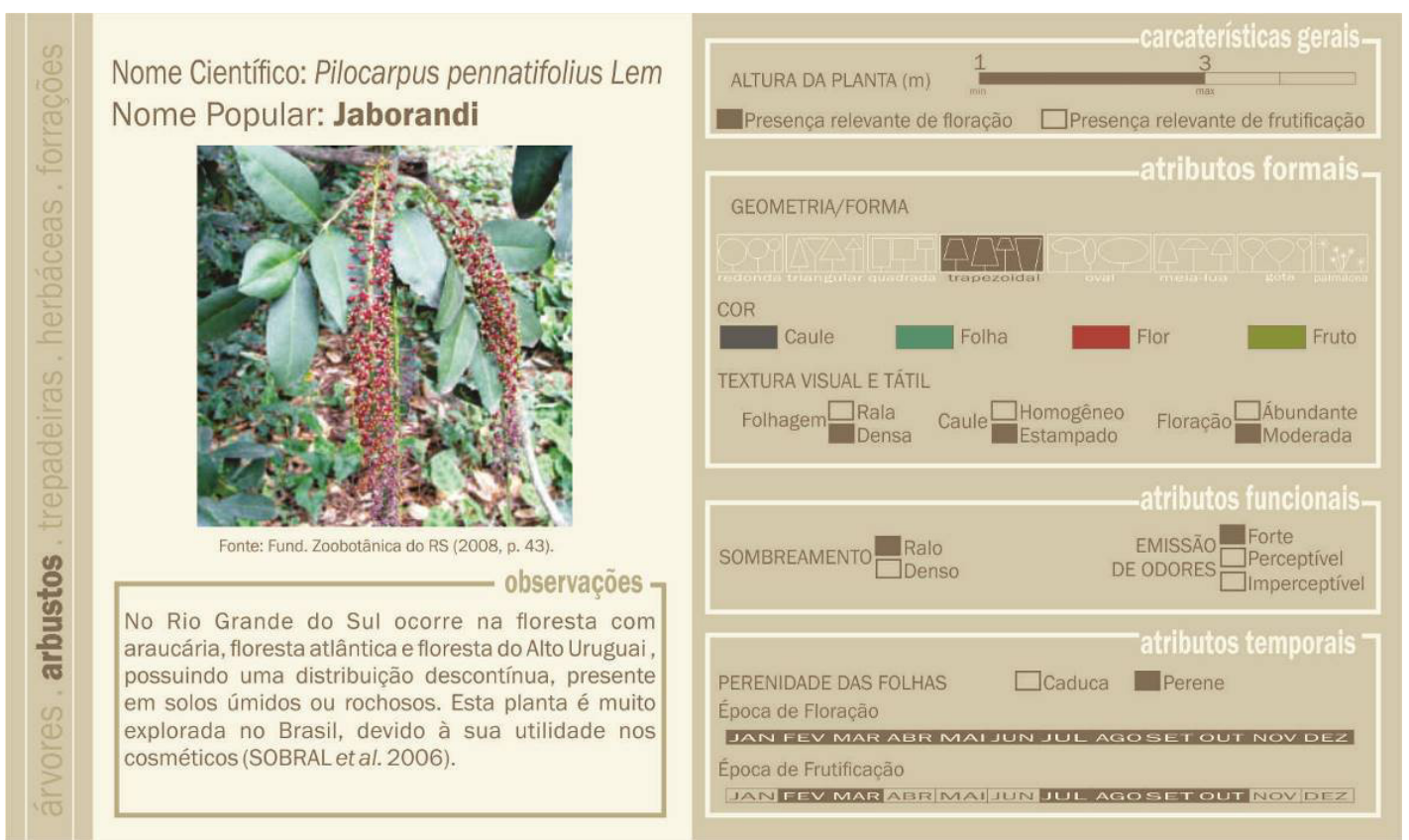

FIGURA 05. Espécie indicadas para a composição dos jardins de chuva subtropical (arbusto). Fonte: Autores (2018) 


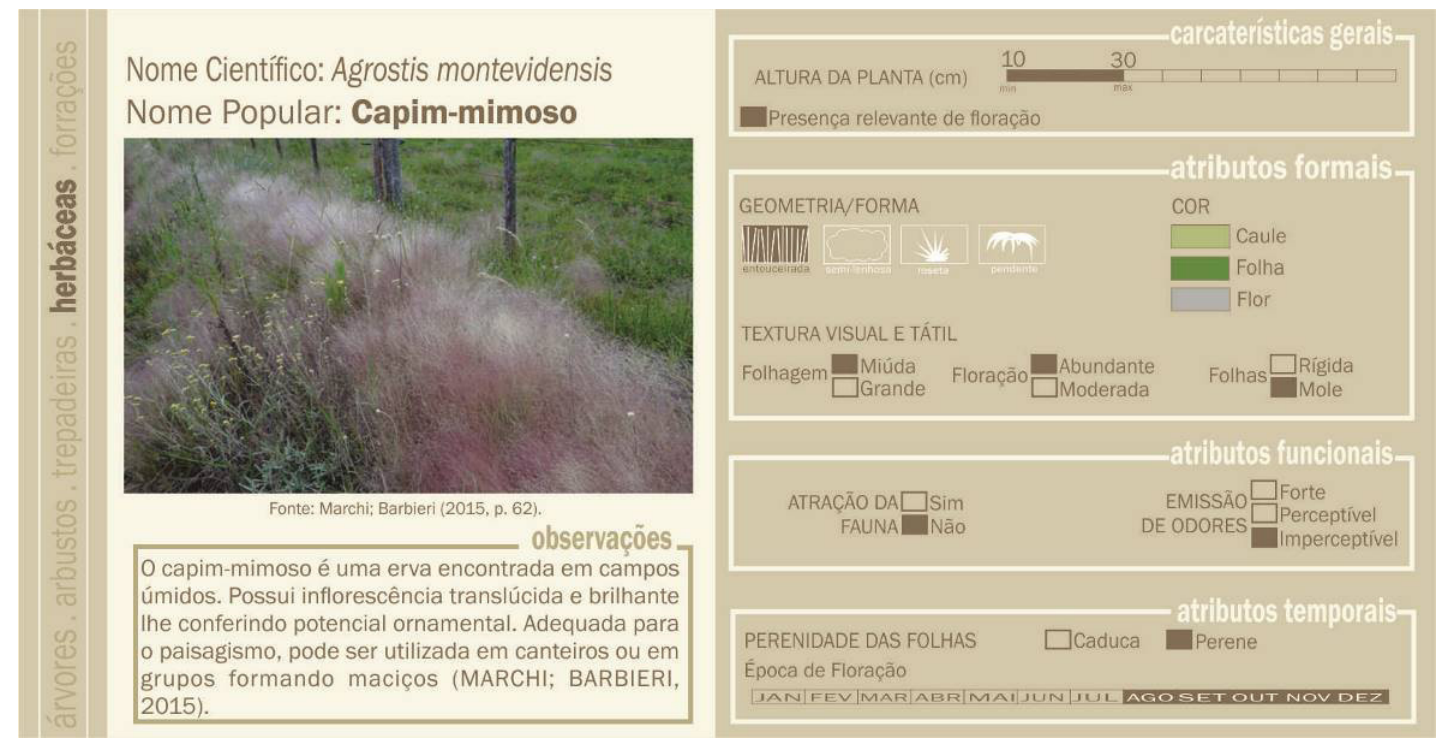

FIGURA 06. Espécie indicadas para a composição dos jardins de chuva subtropical (herbácea).

Fonte: Autores (2018)
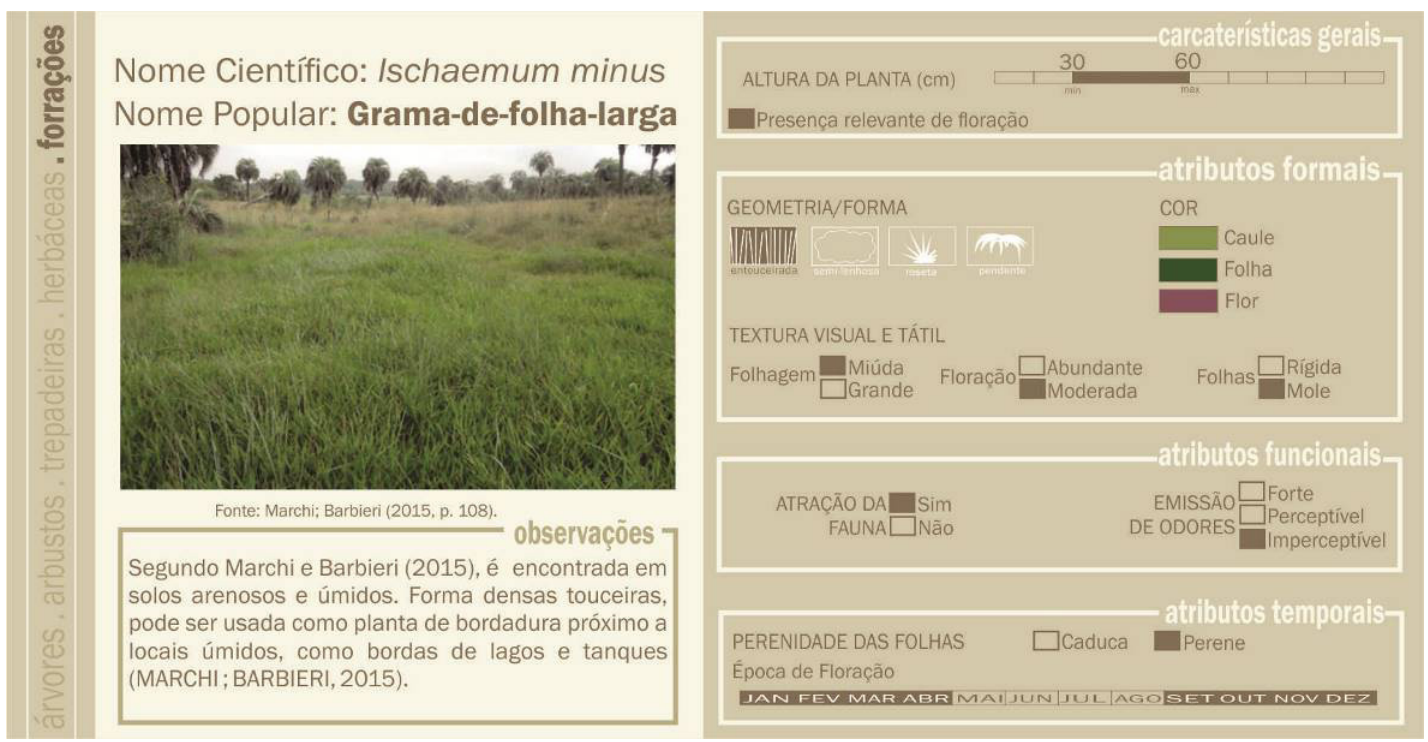

FIGURA 07. Espécie indicadas para a composição dos jardins de chuva subtropical (forração). Fonte: Autores (2018)

\subsection{Sistema de Contenções Vegetadas}

As movimentações de terra devem ser evitadas para diminuir o impacto ambiental, no entanto, muitas vezes se fazem necessárias para a implantação da infraestrutura urbanística. Se as escavações resultam em taludes com declividade muito acentuada, devem ser previstos muros de contenção para evitar a erosão do solo. De acordo com 
Mascaró (2010), o uso da cobertura vegetal é uma solução interessante para evitar a ação da erosão do solo, tanto em taludes quanto em muros de contenção. A implantação da vegetação em taludes contribui com a estrutura do solo, pois aumenta a retenção e a infiltração da água, diminui a velocidade do escoamento das águas pluviais e protege contra o impacto direto das gotas de chuva (BERTONI; NETO, 1990).

As contenções vegetadas (figuras 09 e 10) podem ser estruturadas através de gabiões vegetados, que consistem em uma armação preenchida com pedras em forma de cubo, flexíveis e drenantes combinadas com vegetação, ou estacas vivas que são muros de pedra vegetados, sustentados por fincas de madeira (Vasconcellos, 2015). Mascaró (2010) afirma que a vegetação contribui com a estabilidade das encostas, visto que a inclinação da vegetação informa sobre a estabilidade do terreno e fornece meios para se obter a estabilização das encostas. Quando a declividade é grande, a proteção da encosta pode ser feita por meio de terraços sucessivos sendo que as árvores e arbustos com raízes pivotantes auxiliam na consolidação do terreno. Pode-se também fazer linhas paralelas às curvas de nível e implantar gramíneas, arbustos e árvores de forma que constituem uma barreira, reduzindo a velocidade da descida da água.

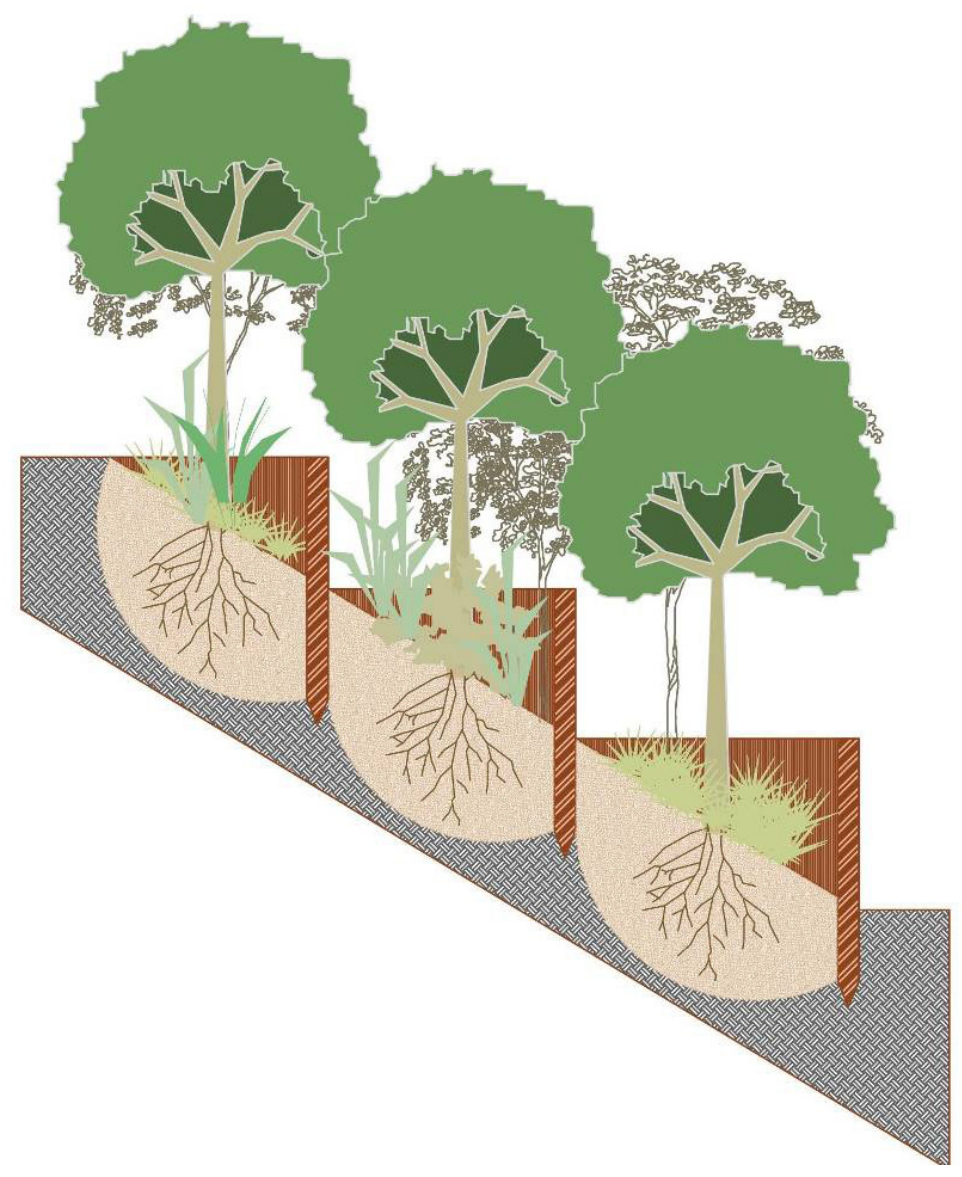

FIGURA 07. Proteção de encostas por meio de terraços sucessivos. Fonte: Adaptado pelos autores de Mascaró e Mascaró (2010). 


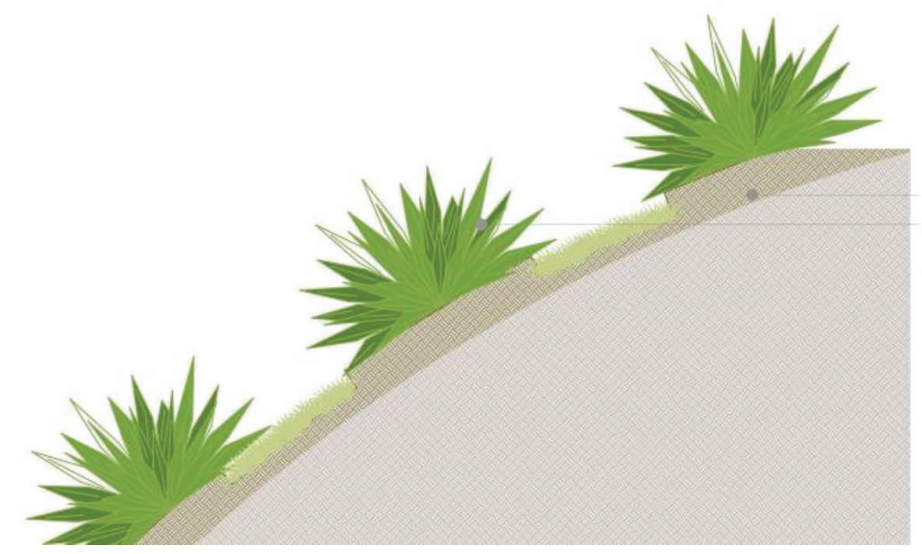

RELVA

ARBUSTOS

FIGURA 08. Proteção de encostas por faixas alternadas de estacas, grama e arbustos. Fonte: Adaptado pelos autores de Mascaró e Mascaró (2010).

Magalhães (2005), afirma que as espécies selecionadas para esse tipo de ambiente devem aceitar grandes declividades, exigir uma baixa demanda de insumos no substrato e devem ser capazes de criar condições favoráveis para a regeneração natural da área. As famílias botânicas indicadas atendem os seguintes aspectos: (i) resistência à seca; (ii) fácil desenvolvimento; (iii) eficácia na cobertura do solo e; (iv) crescimento radicular rápido e profundo. Assim, plantas rasteiras e de grande área foliar são mais efetivas na proteção do solo que plantas eretas e de folhas estreitas (MAGALHÃES, 2005). Nas encostas, quando não existirem patamares, árvores de grande porte devem ser evitadas e podem ser substituídas por arbustos ou outras espécies arbóreas de pequeno porte. Os patamares também ajudam a reduzir a velocidade das águas pluviais, diminuindo o perigo de erosão. Assim, as espécies informadas abaixo (figuras 11 a 15) consistem em gramíneas, leguminosas, trepadeiras e espécies vegetais de porte arbóreo e arbustivo, nativas, que contribuem com o fator de segurança das encostas.

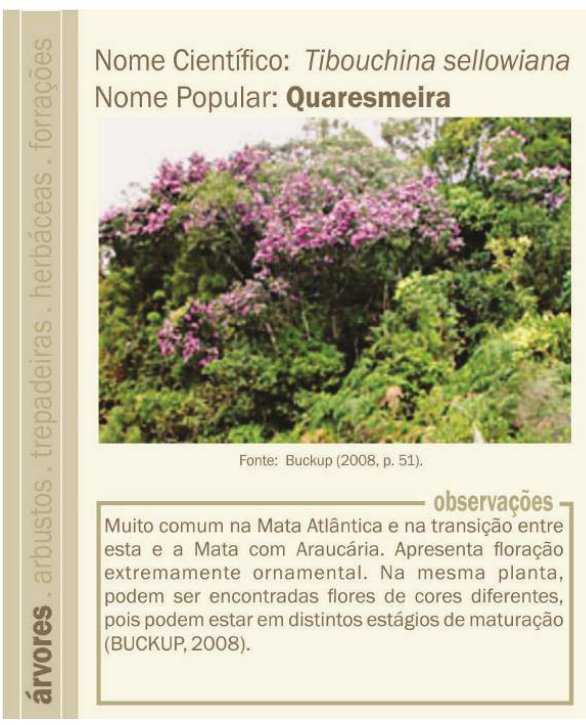

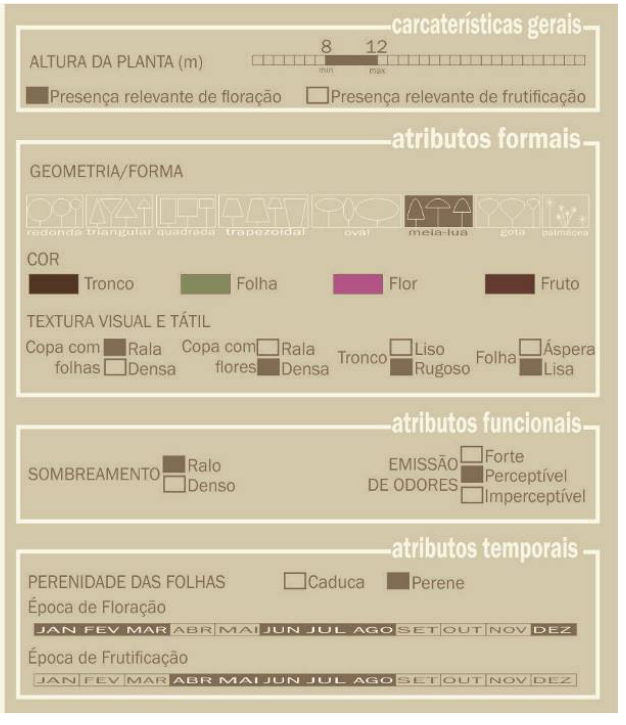

FIGURA 11. Espécies indicadas para contenções em clima subtropical (árvore). Fonte: Autores (2018) 

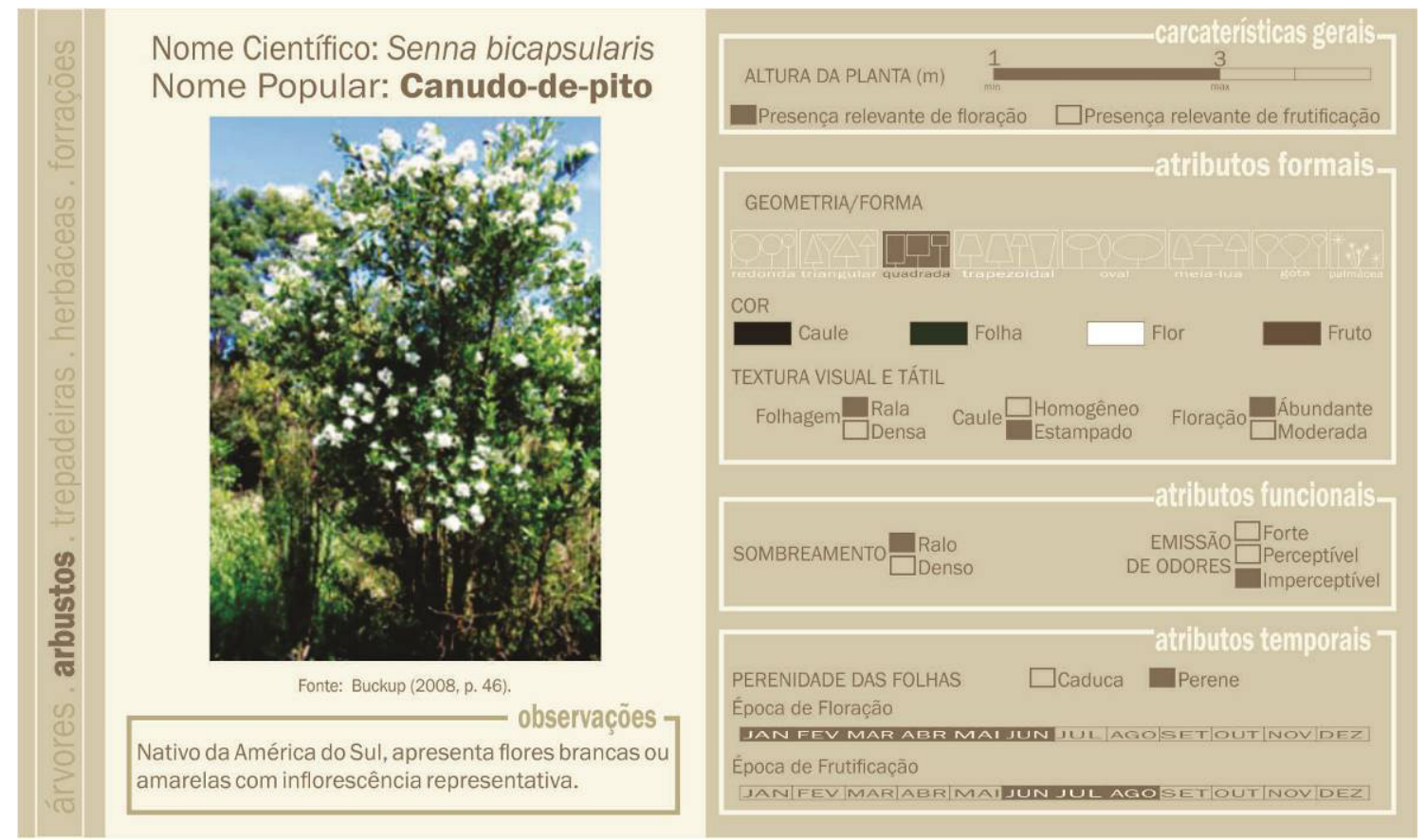

FIGURA 12. Espécies indicadas para contenções em clima subtropical (arbusto).

Fonte: Autores (2018)
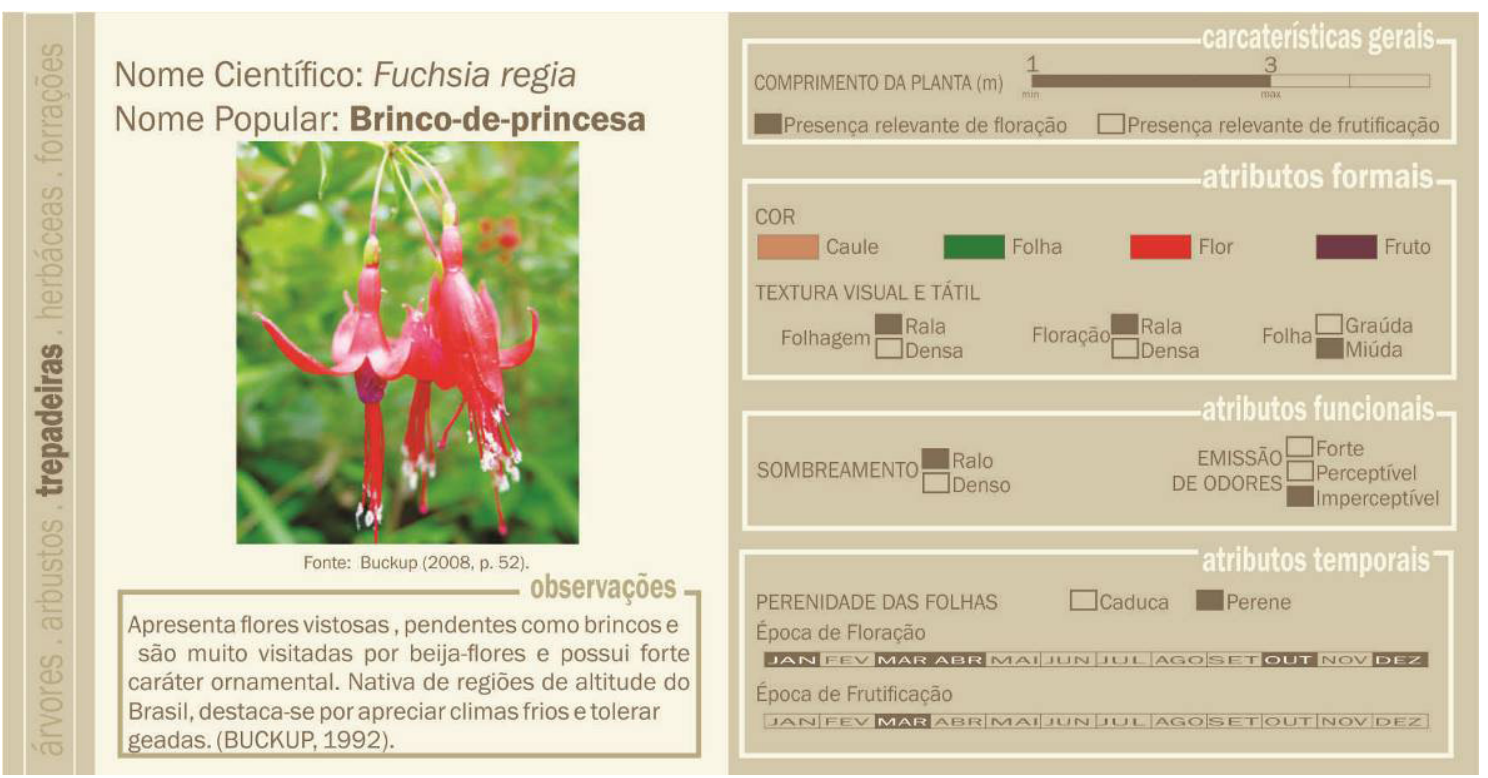

FIGURA 13. Espécies indicadas para contenções em clima subtropical (trepadeira).

Fonte: Autores (2018) 

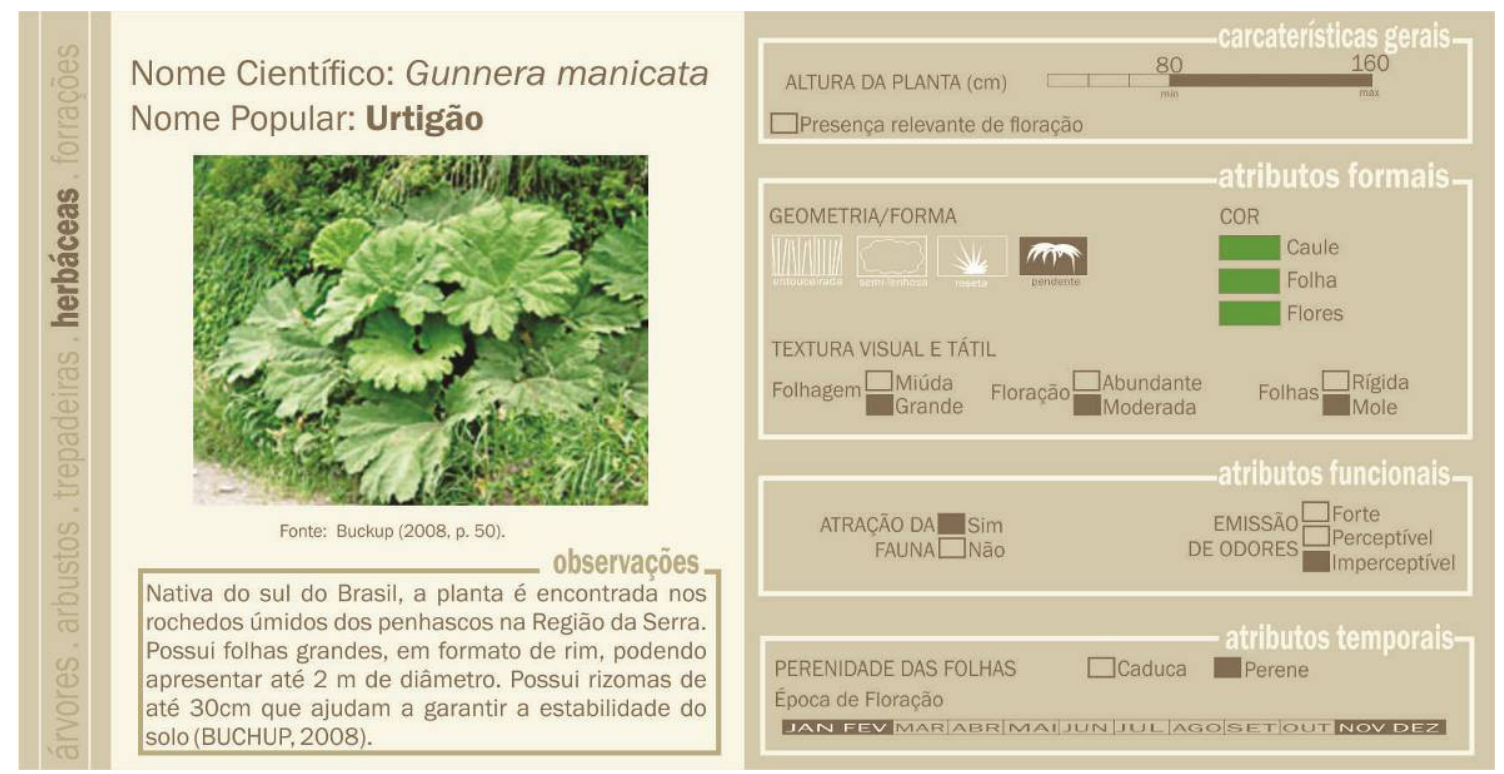

FIGURA 14. Espécies indicadas para contenções em clima subtropical (herbácea).

Fonte: Autores (2018)
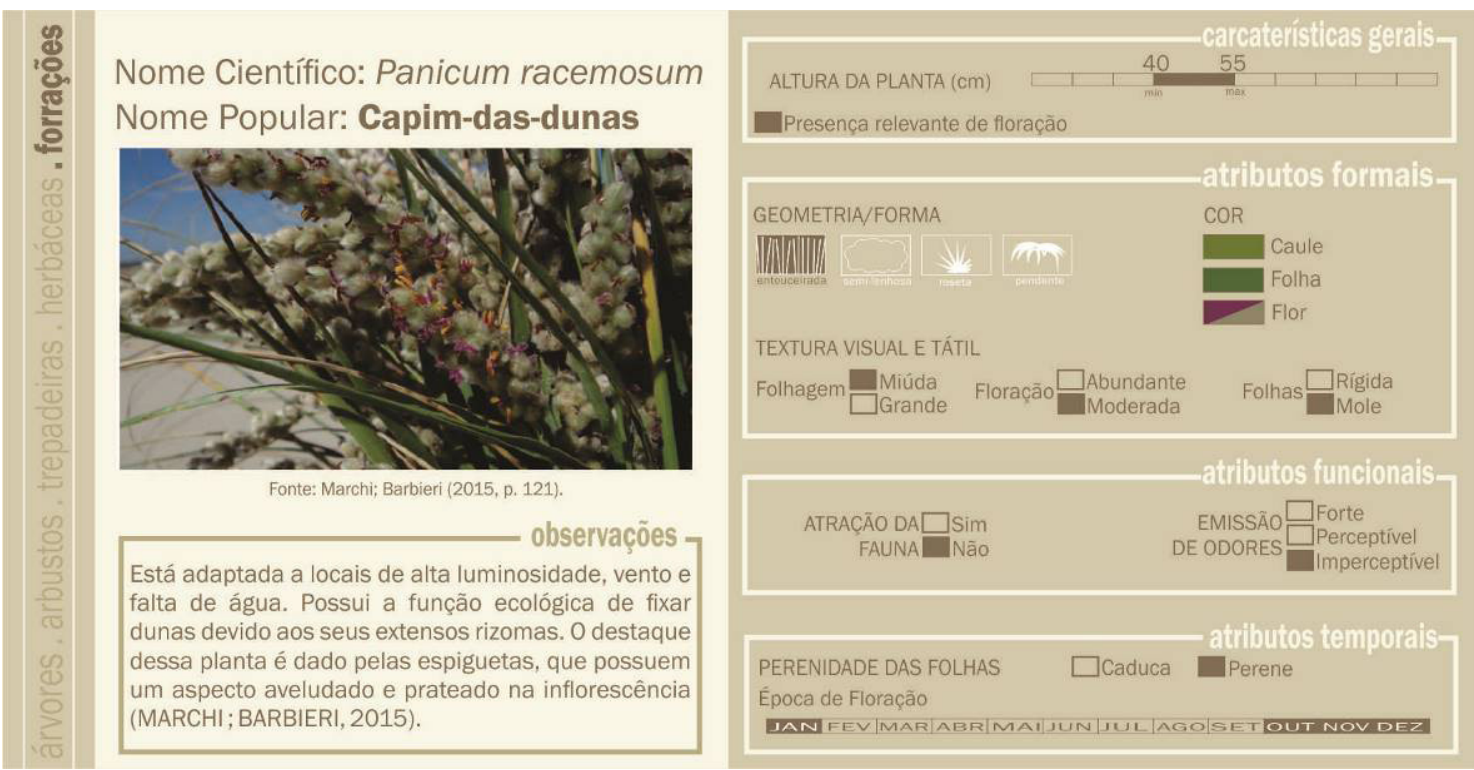

Figura 15. Espécies indicadas para contenções em clima subtropical (forração).

Fonte: Autores (2018)

\subsection{Sistema de biovaletas}

As valetas de biorretenção vegetadas (figura 16) fazem a limpeza da água pluvial e aumentam seu tempo de escoamento, dirigindo este para os jardins de chuva ou sistemas convencionais de retenção e detenção das chuvas (CORMIER; PELLEGRINO, 2008). 
Auxiliam na purificação das águas através da ação de plantas com características de filtragem, fazendo com que aos poucos a água se infiltre no subsolo, chegando nas cotas mais baixas com menor intensidade. Outra vantagem diz respeito à redução considerável da velocidade do escoamento da água que é efetivada pela rugosidade da vegetação associada à sinuosidade e escalonamento do projeto (BONZI, 2015). Conforme Vaconcellos (2015), as funções hídricas são: detenção, purificação por sedimentação, filtração e absorção biológica e condução.

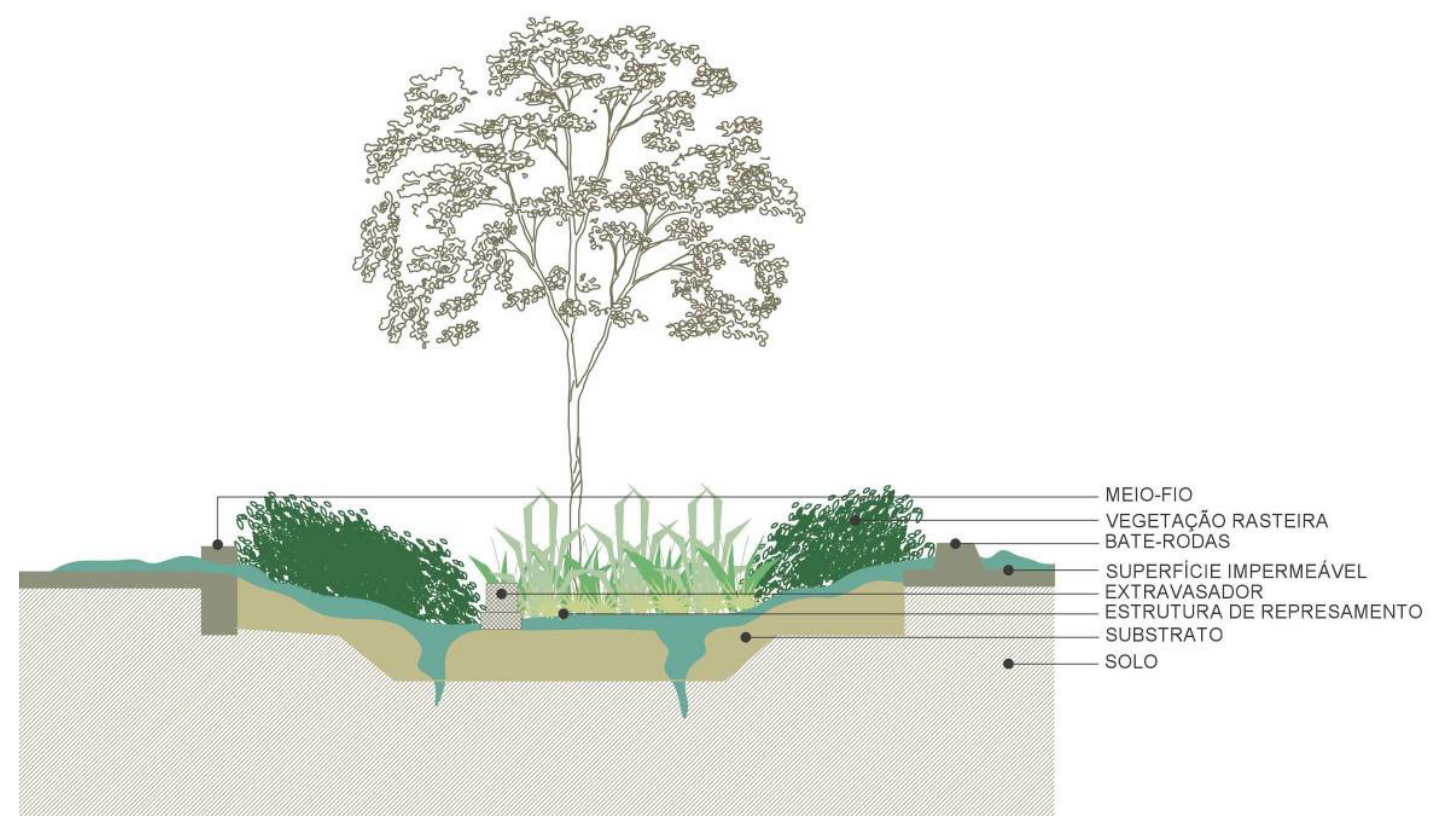

FIGURA 16. Esquema de uma biovaleta. Fonte: Adaptado pelos autores de Bonzi (2015)

Segundo Dias et al (2002), várias espécies de plantas podem crescer em zonas úmidas, no entanto é importante observar os seguintes aspectos: (i) crescimento rápido sob diversas condições; (ii) elevada capacidade de transpiração; (iii) tolerância a diferentes níveis de água e também de secura; (iv) resistência a valores de pH baixos e elevados; (v) crescimento profundo de raízes e rizomas, que contribui quer para o transporte de oxigênio; (vi) construção de novas raízes nos nós quando estes ficam envolvidos por novo material colonizável e; (vii) plantação fácil. As biovaletas também contribuem com a umidificação do ar através da evapotranspiração ocasionada pelas plantas. Conforme afirmam Pott e Pott (2002), todas as espécies aquáticas podem ser consideradas como despoluidoras, a vegetação selecionada (figuras 17 a 21) possui características similares as apresentadas nos canteiros pluviais, além dos aspectos já mencionados, a vegetação deve favorecer a purificação das águas e possuir sua tipologia foliar que favoreça a diminuição da aceleração do escoamento superficial das chuvas. 

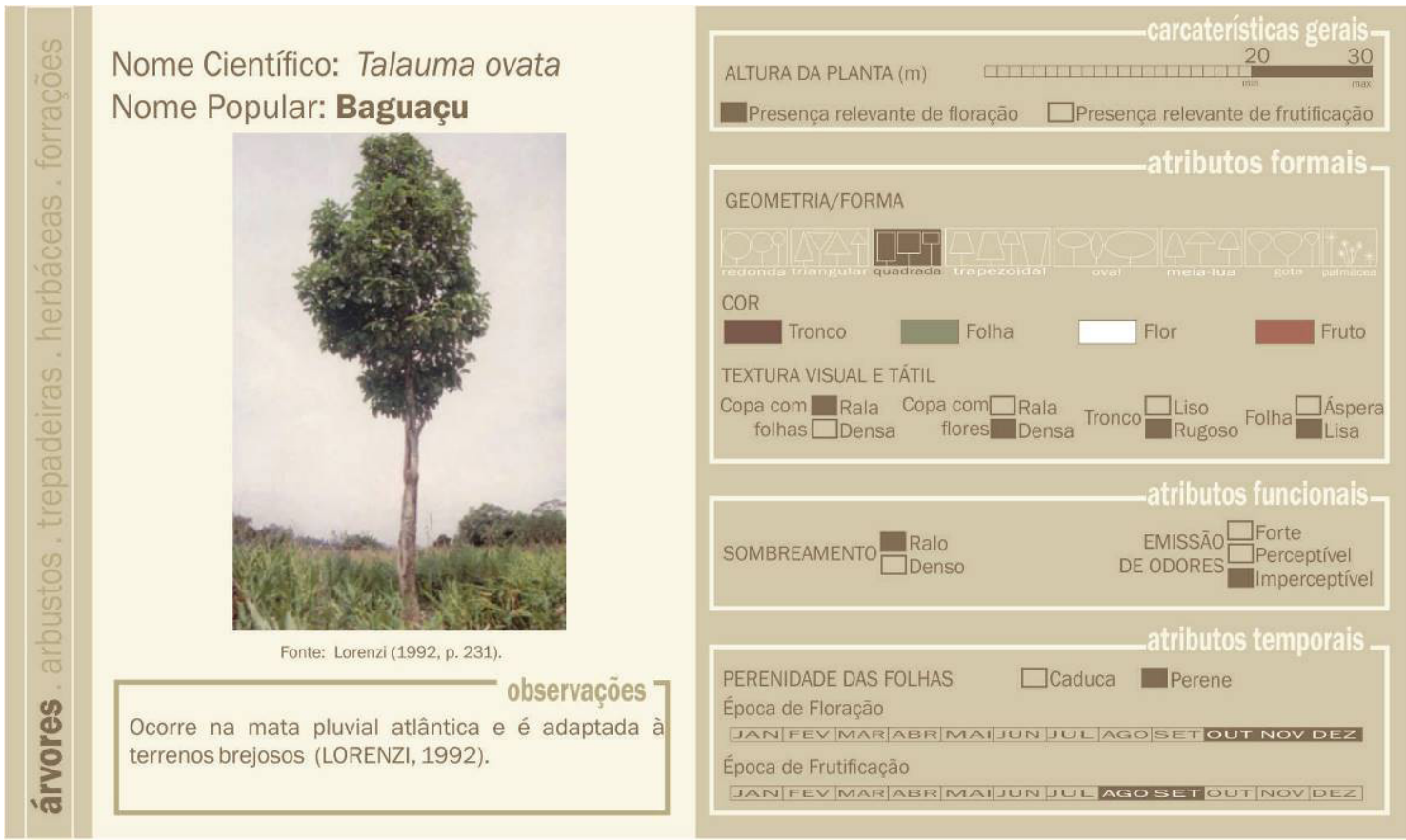

FIGURA 17. Espécies indicadas para biovaletas (árvore). Fonte: Autores (2018)
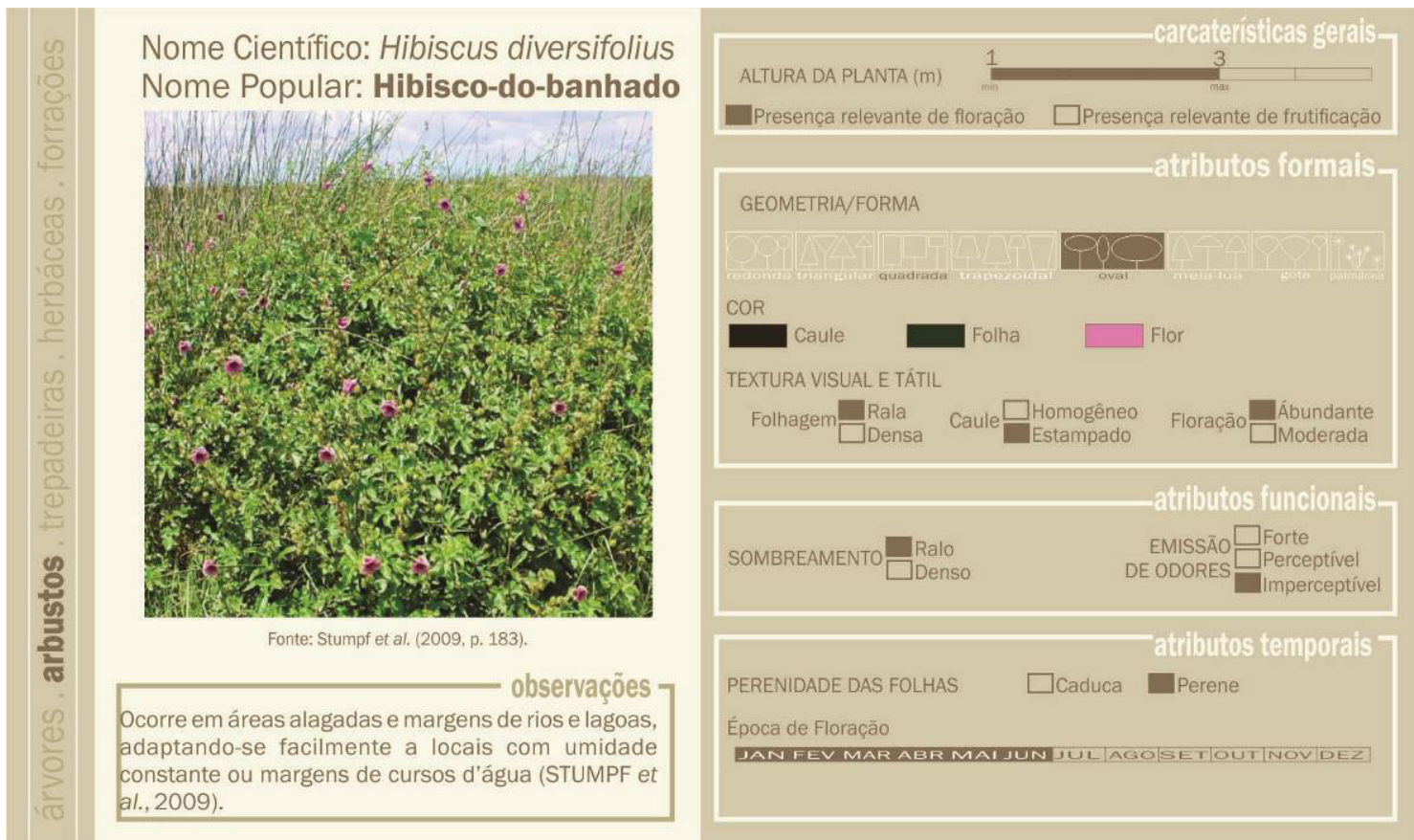

FIGURA 18. Espécies indicadas para contenções em clima subtropical (arbusto).

Fonte: Autores (2018) 

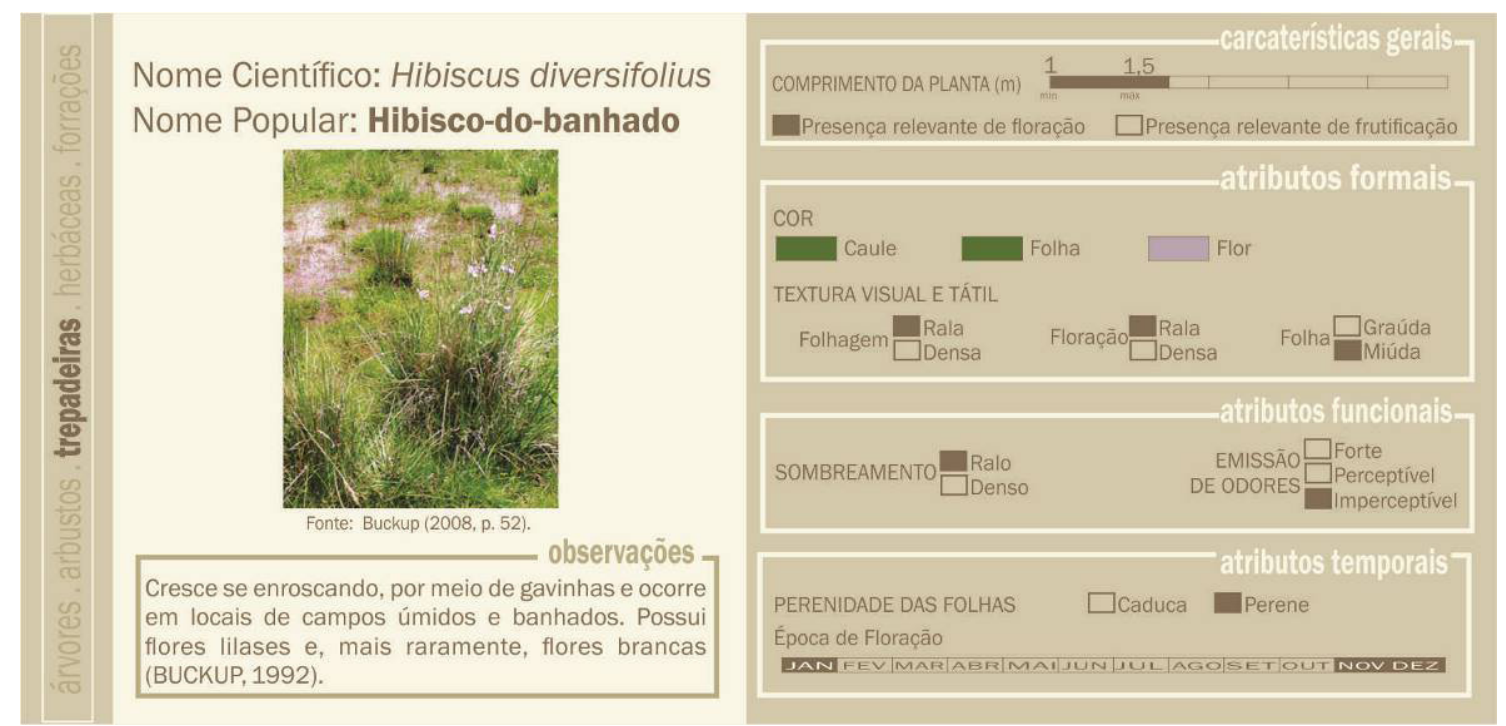

FIGURA 19. Espécies indicadas para contenções em clima subtropical (trepadeira).

Fonte: Autores (2018)
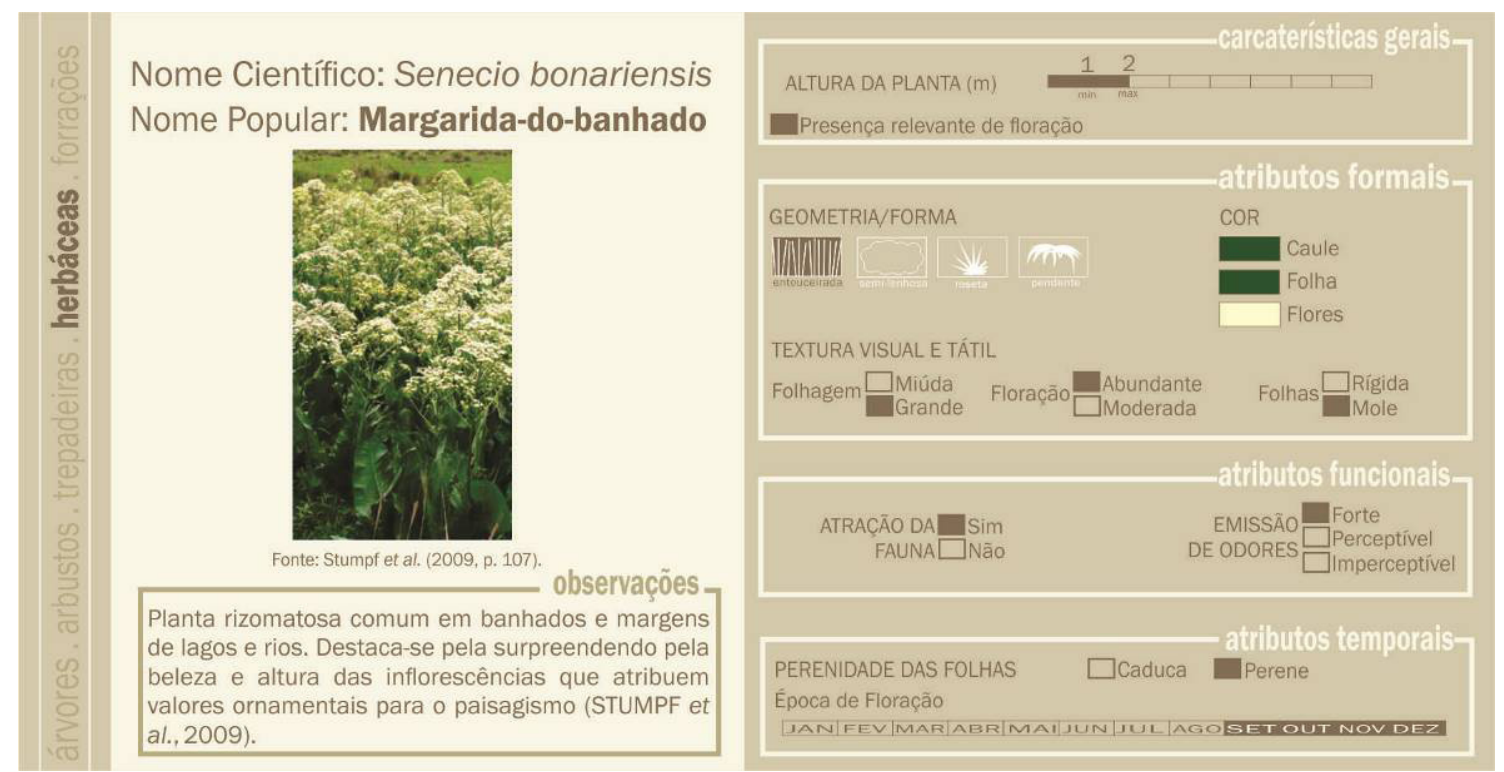

FIGURA 20. Espécies indicadas para contenções em clima subtropical (herbácea).

Fonte: Autores (2018) 


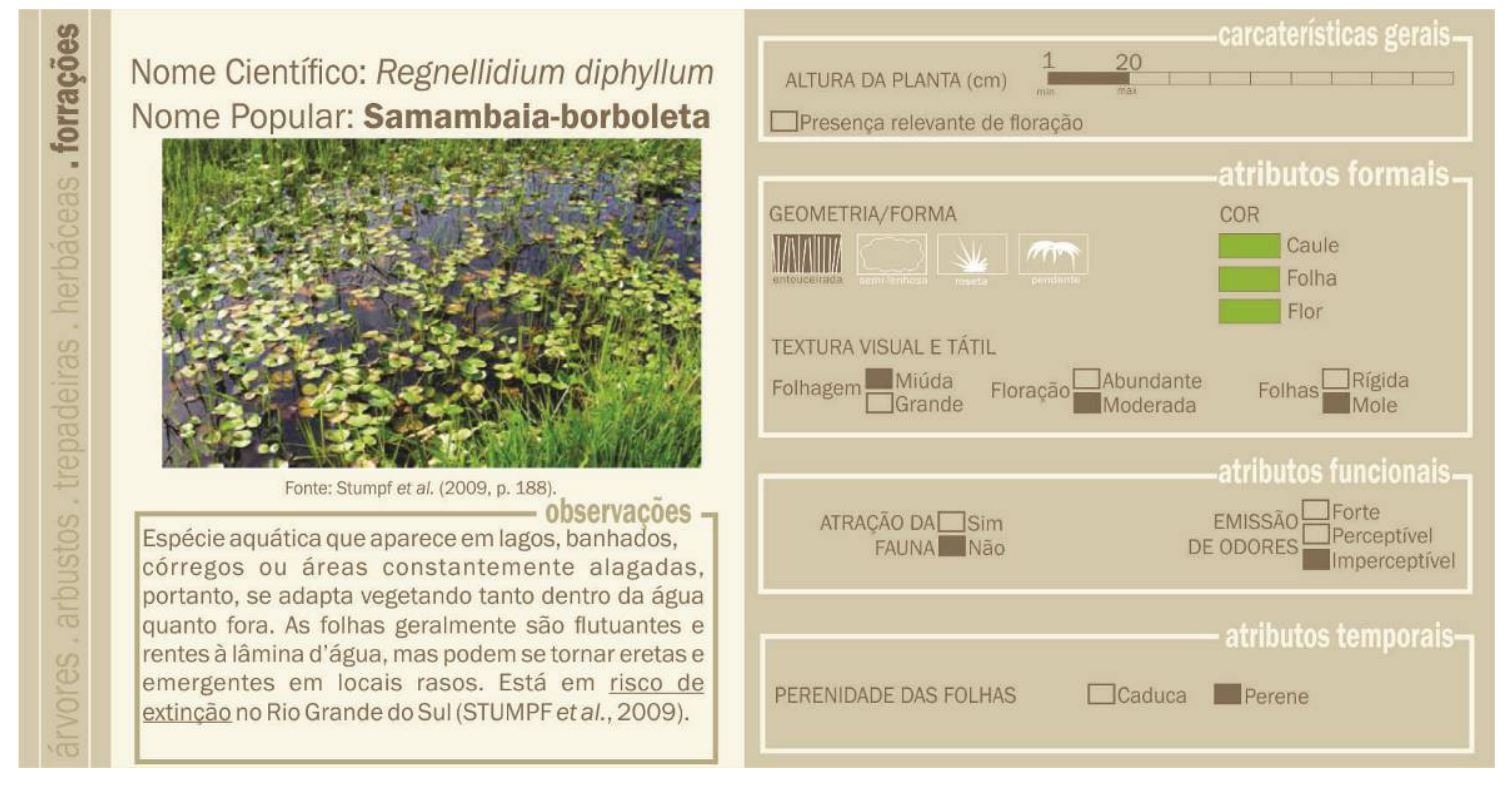

FIGURA 21. Espécies indicadas para contenções em clima subtropical (forração).

Fonte: Autores (2018)

A utilização da vegetação surge como uma solução ecológica para prevenir e proteger os espaços de conexão (PELLEGRINO, 2006) por meio da utilização dos sistemas de infraestrutura verde. Essa prática possibilita a permanência ou recuperação da funcionalidade da paisagem, sendo que, uma das principais funções da utilização da natureza na infraestrutura das cidades, é solucionar problemas de drenagem urbana (VASCONCELLOS, 2015). Dentre os objetivos da incorporação das técnicas da infraestrutura verde para o manejo das águas pluviais estão: proteger corpos de águas urbanos, remover poluentes das águas pluviais, controlar inundações e conter a erosão do solo. "As principais funções exercidas pelas tipologias de infraestrutura verde voltadas para o manejo das águas pluviais são: purificação, detenção, retenção, condução e infiltração" (VASCONCELLOS, 2015:180), sendo este último aspecto de especial interesse para a presente pesquisa.

\section{CONSIDERAÇÕES FINAIS}

Ao longo desta pesquisa foi possível verificar algumas técnicas de infraestrutura verde que estimulam a relação entre o homem e a natureza contribuindo com a qualidade ambiental da paisagem. A inclusão da vegetação, como mecanismo colaborador com as demandas urbanas, vai além das contribuições estéticas, incentivando diversos 
processos naturais que diminuem o impacto causado pela ocupação cinza, tais como: infiltração, filtragem, armazenamento das águas pluviais, aumento da umidade, qualidade e temperatura do ar, criação de habitats, conservação da flora local e diminuição da erosão causada pela movimentação de terra. Visto isso, entende-se que a infraestrutura ecológica contribui de forma significativa com a sustentabilidade das cidades.

A aplicação de espécies nativas é relevante pois existem diversos fatores favoráveis em relação às exóticas, como: adequação aos aspectos climáticos e de relevo; promove o desenvolvimento do crescimento saudável da planta, propicia a preservação da fauna nativa, aumenta a propagação da espécie (dificultando sua extinção); diminui a proliferação de espécies invasoras exóticas e das doenças e pragas causadas pelas mesmas; além de agregar características próprias dos espaços, estimulando o turismo, gerando renda e ampliando o desenvolvimento econômico, cultural e social das cidades.

As espécies vegetais indicadas levaram em consideração as características do ambiente que serão implantadas, sendo que os principais critérios, para a definição da vegetação, foram: (i) espécies nativas; (ii) diversidade de forma e porte; (iii) resistência; (iv) baixa manutenção; (v) capacidade de purificação da água; (vi) resistência a inundações e secas; (vii) raízes pivotantes; (viii) densidade foliar; (iv) baixa demanda de insumos no substrato; $(x)$ crescimento rápido; (xi) raízes profundas e; (xii) rápida regeneração. Para as biovaletas e canteiros pluviais indicou-se espécies que diminuem a toxicidade da água e resistem a períodos de cheias e secas. As contenções foram relacionadas às espécies que contribuem com a resistência à erosão e resistem a alta declividade, substrato com poucos nutrientes e a ventos fortes.

Ou seja, existem diversas tipologias de vegetação nativas, de portes variados que estão aptas para as mais diversas condições de ambiente, proporcionando a formação de massas vegetais e qualificando a ambiência urbana. As indicações de espécies expostas representam apenas uma pequena parcela dentro de muitas outras opções de exemplares que existem no meio ambiente natural, portanto, acredita-se que existe um campo maior para pesquisas futuras que incorporem estudos junto à realidade brasileira, contribuindo com um catálogo maior de espécies, e ainda, incorporando outros climas e tipologias de infraestrutura verde. 


\section{REFERÊNCIAS BIBLIOGRÁFICAS}

ALMEIDA, G. W. Aspectos Ecológicos da comunidade de macrófitas aquáticas na represa do funil, MG - Perspectiva para o manejo. Tese apresentada à Universidade Federal de Lavras no curso de pós-graduação em ecologia aplicada para o título de doutor. Lavras. 2012.

ALMEIDA, R. A.; OLIVEIRA, L. F. C.; KLIEMANN, H. J. Eficiência de espécies vegetais na purificação de esgoto sanitário. Goiânia-GO, Brasil. Pesq Agropec Trop 37(1): 1-9, mar. 2007. Disponível em: <https://cvcarlosjorgeferreira.files.wordpress.com/2012/04/trab-final-geoambiente1.pdf >. Acesso em 31 de jan de 2017.

BARGOS, D. C; MATIAS, L. F. Áreas verdes urbanas: um estudo de revisão e proposta conceitual Piracicaba, SP. Soc. Bras. de Arborização Urbana REVSBAU, v.6, n.3, p.172-188, 2011.

BERTONI, J; NETO, F. L. Conservação do solo. São Paulo: Ícone. 1990. 355 p.

BONZI, R. S. Andar sobre a água: a aplicação da Infraestrutura Verde em áreas densamente urbanizadas. Dissertação apresentada à Faculdade de Arquitetura e Urbanismo da Universidade de São Paulo para obtenção do título de Mestre em Arquitetura e Urbanismo. São Paulo. 2015.

BUCKUP, G. B. Biodiversidade dos campos de Cima da Serra. Porto Alegre: Libretos, 2008. 196 p.

CORMIER, N. S.; PELLEGRINO, P. R. M. Infraestrutura verde: uma estratégia paisagística para a água urbana. Paisagem Ambiente: ensaios. n. 25. São Paulo. p.125 - 142. 2008. Disponível em:

DIAS, P. F; FILHO, S. T. C; ARONOVICH, S; SOUTO, S. M; SCHIMIDT, L. T. Avaliação de vinte oito cultivares de alfafa em Paty do Alferes, Rio de Janeiro. Rio de Janeiro: Agronomia. v:36. $n^{\circ}$ 1/2. 2936 p. 2002.

ELY, V. H. M. B.; CASTRO, J.; GOULART, V. D.; ZOCCOLI, A.; KOELZER, M. P.; JUNIOR, O. A. W. Desenho Universal aplicado ao Paisagismo. Florianópolis. Universidade Federal de Santa Catarina. 210. $110 \mathrm{p}$.

ESTEVES, F. A.; CAMARGO, A. F. M. Sobre o papel das macrófitas aquáticas na estocagem e ciclagem de nutrientes. Acta Limnologica Brasileira. São Carlos. v.1. p 273-298.1986.

FUNDAÇÃO ZOOBOTÂNICA DO RIO GRANDE DO SUL. Guia do Jardim Botânico de Porto Alegre. 2. ed. Porto Alegre. 2008. 100p.

GALINDO, I. C. L.; RIBEIRO, M; SANTOS M. F. A. V.; LIMA, J. F. W. F.; FERREIRA, R. F. A. L. Relações solo-vegetação em áreas sob processo de desertificação no município de Jataúba/PE. R. Bras. Ci. Solo, 32:1283-1296, 2008. 
GIACOMELI, D. C. Caracterização da arborização viária e sua influência no microclima urbano na escala do pedestre. Dissertação apresentada ao Programa de Pós-Graduação em Engenharia Urbana da Universidade Federal de São Carlos, como parte dos requisitos para a obtenção do título de Mestre em Engenharia Urbana. São Carlos. 2013. Disponível em: <http://www.revistas.usp.br/paam/ article/download/105962/111750>. Acesso em: 08 de dez de 2016.

JACOBS, J. Morte e vida de grandes cidades. Tradução Carlos S. Mendes Rosa. São Paulo: Martins Fontes, 2003.

LORENZI, H. Árvores brasileiras: manual de identificação e cultivo de plantas arbóreas nativas do Brasil, vol. 1, 3. ed. Nova Odessa, SP: Instituto Plantarum, 1992. 351p.

LORENZI, H.; SOUZA, H. M. Plantas ornamentais do Brasil. Arbustivas, herbáceas e trepadeiras. 3.ed. Nova Odessa: Instituto Plantarum, 2001. 1088p

MAGALHÃES, A. F. Avaliação do desempenho de técnicas de bioengenharia na proteção e conservação da cobertura final de taludes em aterros de disposição de resíduos sólidos urbanos: estudo de caso para o aterro sanitário de belo horizonte, MG. Dissertação apresentada ao Programa de Pós-graduação em Saneamento, Meio Ambiente e Recursos Hídricos da Universidade Federal de Minas Gerais, como requisito parcial à obtenção do título de Mestre em Saneamento, Meio Ambiente e Recursos Hídricos. Belo Horizonte. 2005.

MAGALHÃES, L. M.; CRISPIM, A. A. Vale a pena plantar e manter árvores e florestas na cidade ciência? Ciência Hoje. v. 33. 2003.

MARCHI, M.; BARBIERI, R. L. Cores e formas no bioma pampa: gramíneas ornamentais nativas. Editoras técnicas - Brasília, DF: Embrapa, 2015

MASCARÓ, J. L. Loteamentos Urbanos. Masquatro Editora. Porto Alegre. 2010. 210p.

MASCARÓ, J. L.; MASCARÓ, L. Vegetação Urbana. UFRGS. Porto Alegre. 2010. 242p.

MCHARG, I. L. Proyectar com la naturaleza. México. Gustavo Gili S.A. 2000.

MEDEIROS. C. F. Paisagem e Drenagem Urbana: estratégias de infraestrutura verde para a revitalização do centro histórico tombado de Laguna/SC. Dissertação apresentada ao Programa de Pós- Graduação em Arquitetura e Urbanismo da Universidade Federal de Santa Catarina, como um dos requisitos para obtenção do título de Mestre em Arquitetura e Urbanismo. Florianópolis. 2015.

MELLO FILHO, L. E. Arborização urbana. Encontro Nacional sobre Arborização Urbana, I, 1985. Porto Alegre. Anais... Porto Alegre, 1985. p. 45-49.

MYERS, N.; MITTERMEIER, R. A.; MITTERMEIER, C. G.; FONSECA, G. A. B. E KENT, J. Biodiversity hotspots for conservation priorities. Nature 403: 853-858. 2000. 
PELLEGRINO, P. R. M. Pode-se planejar a paisagem? Paisagem e Ambiente: ensaios São Paulo: Faculdade de Arquitetura e Urbanismo, n¹3, dez de 2000. P. 159-180.

POTT V. J.; POTT A. Potencial de uso de plantas aquáticas na despoluição da água. Campo Grande. Embrapa. 2002. 25 p.

RIZZINI, C. T.; MORS, W. B. Botânica econômica brasileira. Rio de Janeiro: Ambito Cultural Edições, 1995. 248p.

ROMERO, M. A. B. Princípios Bioclimáticos para o desenho Urbano. UNB. 2001. 128p.

SEOANE, C. E. S. Conservação da diversidade Florestal. Anais VIII Semana de Estudos Florestais. Irati, PR. 2006.pg 110. 23 a 27 de outubro de 2006.

SOBRAL, M.; JARENKOW, J. A.; BRACK, P., IRGANG, B.; LAROCCA, J; RODRIGUES, R. S. Flora arbórea e arborescente do Rio Grande do Sul, Brasil. São Carlos. Editora Rima. 2006. 350 p.

SOUSA, A. S.; GOULART, S. V; ARAÚJO, V. M. D. Vegetação como atenuador do clima local: critérios para a escolha de espécies vegetais para instituição de ensino em um clima quente-úmido. XV ENCONTRO NACIONAL DE TECNOLOGIA DO AMBIENTE CONSTRUÍDO. Nov. 2014. Maceió.

STUMPF, E. R. T.; BARBIERI, R. L. Cores e formas no Bioma Pampa: plantas ornamentais nativas. Pelotas. Embrapa Clima Temperado. 2009. 276p.

STUMPF, E. R. T.; SILVA P; ROMAGNOLI, I. D.; FISCHER, S. Z.; MARIOT, M. P. Espécies nativas que podem substituir as exóticas no paisagismo. Ornamental Horticulture. V. 21, N.2, 2015, p. 165-17.

THOMAZ, S. M. e BINI, L. M. Ecologia e manejo de macrófitas aquáticas em reservatórios. Acta Limnologia Brasiliensia. Maringá: EDUEM. v. 10. 103-116 p. 1998. Disponível em: <http://www.ablimno.org.br/ acta/pdf/acta_limnologica_contents1001E_files/Artigo\%209_10(1).pdf>. Acesso em: 08 de dez de 2016.

VARGAS, H. C.; PELLEGRINO, P. R. M. Estratégias para uma infraestrutura verde. Manole. 2017. 317p.

VASCONCELLOS, A. A. Infraestrutura verde: Aplicada ao planejamento da ocupação urbana. Appris. 2015. 229 p. 